Civic Engagements 



\section{Civic Engagements}

The Citizenship Practices of Indian and Vietnamese Immigrants

Caroline B. Brettell and Deborah Reed-Danahay 


\section{Stanford University Press}

Stanford, California

()2012 by the Board of Trustees of the Leland Stanford Junior University. All rights reserved.

No part of this book may be reproduced or transmitted in any form or by any means, electronic or mechanical, including photocopying and recording, or in any information storage or retrieval system without the prior written permission of Stanford University Press.

Printed in the United States of America on acid-free, archival-quality paper

Library of Congress Cataloging-in-Publication Data

Brettell, Caroline, author.

Civic engagements : the citizenship practices of Indian and Vietnamese immigrants / Caroline B. Brettell and Deborah Reed-Danahay.

pages $\mathrm{cm}$

Includes bibliographical references and index.

ISBN 978-0-8047-7528-1 (cloth : alk. paper)--ISBN 978-0-8047-7529-8 (pbk. : alk. paper)

1. East Indian Americans--Political activity--Texas. 2. Vietnamese Americans--Political activity-Texas. 3. East Indian Americans--Texas--Societies, etc. 4. Vietnamese Americans--Texas-Societies, etc. 5. Immigrants--Political activity--United States--Case studies. 6. Immigrants-United States--Societies, etc.--Case studies. I. Reed-Danahay, Deborah, author. II. Title.

F395.E2B74 2012

323.1191'40764--dc22

2011015777

Typeset by Bruce Lundquist in 10/14 Minion 